University of Rhode Island

DigitalCommons@URI

\title{
Trust in social media brands and perceived media values: A survey study in China
}

\author{
Mingmin Zhang \\ Ping $\mathrm{Xu}$ \\ University of Rhode Island, pingxu@uri.edu \\ Yinjiao Ye \\ University of Rhode Island, yinjiao_ye@uri.edu
}

Follow this and additional works at: https://digitalcommons.uri.edu/psc_facpubs

The University of Rhode Island Faculty have made this article openly available.

Please let us know how Open Access to this research benefits you.

This is a pre-publication author manuscript of the final, published article.

Terms of Use

This article is made available under the terms and conditions applicable towards Open Access

Policy Articles, as set forth in our Terms of Use.

\section{Citation/Publisher Attribution}

Zhang, M., Xu, P., \& Ye, Y. (2021). Trust in social media brands and perceived media values: A survey study in China. Computers in Human Behavior, 127, 107024. https://doi.org/10.1016/j.chb.2021.107024

Available at: https://doi.org/10.1016/j.chb.2021.107024 


\title{
Trust in Social Media Brands and Perceived Media Values:
}

\section{A Survey Study in China ${ }^{1}$}

\author{
Mingmin Zhang \\ Assistant Professor \\ Department of Journalism and Communication \\ South China Normal University \\ zhangmingmin@scnu.edu.cn
}

Ping $\mathrm{Xu}$

Associate Professor

Department of Political Science

University of Rhode Island

Email:pingxu@uri.edu

\author{
Yinjiao Ye \\ Professor \\ Department of Communication Studies \\ University of Rhode Island \\ Email: yinjiao_ye@uri.edu
}

\footnotetext{
1 This paper is published in Computers in Human Behavior in 2021. For questions, please contact Profs. Ping Xu and Yinjiao Ye.
} 


\begin{abstract}
Chinese social media platforms such as WeChat, TikTok (Douyin in Chinese), and Weibo have become increasingly popular, attracting large amounts of loyal users in and outside of China. Borrowing theories on brand trust and perceived brand values from Marketing and Management, this study examines how perceived media values influence trust in Chinese social media brands such as Weibo and WeChat. Utilizing original survey data collected from Chinese social media users, our study finds that: (1) Chinese users perceive five layers of values in using social media applications, including information value, entertainment value, social networking value, social status value, and organizational communication value; (2) these perceived media values have different effects on trust in social media brands: while entertainment value, social networking value, and social status value directly affect social media brand trust, information value and organizational communication value indirectly affect social media brand trust through social status value, social networking value and/or entertainment value. Our study suggests an important explanation for trust in social media and develops a scale of perceived media values (PMV) that can be used by future researchers.
\end{abstract}

Keywords: perceived media value, social media, brand trust, structural equation model, scale development 


\section{Introduction}

The emergence of the Web 2.0 technology has changed the dynamics of the media system. In China, various social media platforms such as WeChat, TikTok and Weibo have become increasingly popular, attracting large amounts of users at home and abroad in recent years. For instance, WeChat alone had 1.24 billion monthly active users as of the first quarter of 2020 (Iqbal, 2021), and TikTok attracted 100 million monthly active users in the US alone as of August 2020 (Sherman, 2020). The TikTok user base has become so large that the Trump administration even saw it as a threat to national security and issued an executive order to ban the application along with WeChat in the US. It is intriguing how social media sites such as WeChat and TikTok have attracted such a large loyal user base within China and around the world. Is there anything unique about these social media platforms that make their users trust these brands?

For social media sites themselves, user traffic is directly associated with their revenue. Popular sites with high user traffic can make a sizable profit from commercials. For instance, TikTok's advertisement revenue topped 27.2 billion dollars in 2020, thanks to its high levels of user traffic (Zhu \& Yang, 2020) . However, in today's online environment, it is not uncommon for new or other social media applications to imitate the functions of existing social media sites in order to attract users. Due to low levels of cost to access social media sites and nearly no barriers in transferring between sites, retaining users and promoting user loyalty and trust has 
become an important question for social media companies. Brand trust is important also because it directly influences users' decisions to visit the brand site, share information, disclose user information, make a purchase, and conduct networking activities on the site, as well as brand equity and brand loyalty (Dwyer, Hiltz, \& Passerini, 2007; Ebrahim, 2020; Lumsden \& MacKay, 2006; Metzger, 2004; PSRA, 2002; Ulusu, Durmus, \& Yurtkoru, 2011). Media trust also predicts users' diagnosis of fake news on social media (Chen \& Cheng, 2019).

Considering the increasingly popularity of Chinese social media brands and the growing difficulty for social media brands to retain trust among users, we set to explore determinants of social media brand trust by using Chinese social media as an example. Generally speaking, there is a lack of academic research on trust in social media brands with only a few exceptions (Dwivedi, Johnson, Wilkie, \& Araujo-Gil, 2019; Pentina et al., 2013). Limited existing studies are based mostly on western countries and have explored brand trust and its determinants, such as user experience, consumer perception of product or brand value, brand knowledge, consumer satisfaction, consumer familiarity with brands, consumption habits, and knowledge of alternatives (Barnes \& Bohringer, 2011; Chen \& Cheng, 2019; Delgado-Ballester \& Munuera-Alemán , 2005 ; Garbarino \& Johnson, 1999; Gu, Oh \& Wang, 2009; Laroche et al., 2012; Liu, Lee, Liu, \& Chen, 2018; Park, Kee, \& Valenzuela, 2009; Pelling \& White, 2009; Pookulangara \& Koesler, 2011). Yet, this stream of research on brand trust has not been extended much into the field of media, especially trust in social media brands. 
Our study aims to fill this gap by explaining trust in social media brands in the context of China.

\section{Literature Review}

\subsection{Brand Trust and Its Determinants}

Trust is a core element in the study of consumer-brand relationship (Blackston, 1992; Garbarino \& Johnson, 1999; Liu, Lee, Liu, \& Chen, 2018; Morgan \& Hunt, 1994). Brand trust is defined as the willingness of consumers to trust a brand and expect positive results even in the face of risk (Lau \& Lee, 1999). On the one hand, consumers expect positive results of their brand selection and believe that the brand can fulfill its brand value (Chaudhuri, 2001).

Delgado-Ballester (2003) contends that while interacting with a brand, consumers generate a sense of security if they perceive the brand is reliable and responsible for their interests and welfare. On the other hand, risk is a key condition for brand trust (Bhattacharya, Debinney, \& Pillutla, 1998) and indicates consumers' uncertainty in brand choice and perceived sacrifice.

Scholars have long explored sources of brand trust, such as consumers' brand knowledge, brand use experience and familiarity with the brand as explanations (Delgado-Ballester \& Munuera-Alemán, 2005; Garbarino \& Johnson, 1999; Laroche et al., 2012). Brand use experience generates consumer brand awareness and brand association. Brand familiarity brings a better brand-consumer relationship, thereby forming higher levels of brand trust. Wang et al. (2010) argue that consumers' brand knowledge and experience are the 
sources of brand trust and propose that brand trust comes from three channels: advertising, word-of-mouth and user experience, with the impact of user experience being the greatest.

Perceived brand value is also related to brand trust. Zeithaml (1988) defines perceived brand value as a consumer's overall assessment of the utility of a product or service based on perceptions of what is received and what is given. Perceptions of what is received may include the internal and external attributes, quality, and other highly abstract features of the product, and these features influence product perceptions. Perceptions of what is given are mainly reflected through monetary and non-monetary prices, namely perceived brand value (Kantamneni \& Coulson, 1996; Petrick, 2002; Sheth, Newman \& Gross 1991; Sweeney \& Soutar, 2001). Most scholars agree that perceived brand values include functional value (perceived quality and expected performance of the product), social value (the product's ability to enhance social self-concept), personal value (an expression of consumers' self-fulfillment needs), and emotional value (the utility derived from the feelings or affective states that a product generates) (Keller, 2008; Kantamneini \& Coulson, 1996; Petrick, 2002; Sweeney \& Soutar, 2001). Evidence shows the driving effect of perceived value on brand trust. Chaudhuri and Holbrook (2001) found a significant positive correlation between perceived value and brand trust. Chi, Yeh and Chiou ( 2009 ) reported perceived brand value was positively related to brand trust in a survey of female users of cosmetic products, which was replicated by Zohaib and Muhammad ( 2014 ) through an investigation of Hewlett Packard product consumers. Prameka's ( 2016 ) research demonstrated that a higher level of perceived value of products and 
services could lead to a higher level of brand trust. Moliner (2009) reported the significant impact of patients' perceived value on trust in the health care market. Harris and Goode (2004) confirmed that consumers' perception of brand value had a significant impact on brand trust through a survey of online ticket purchasers. Ercis' (2012) research reported that brand value and quality had a significant effect on brand trust. Ulaga and Eggert (2006) showed that brand value was a prerequisite for a quality brand-consumer relationship.

With the development of social media, consumers can easily share their brand experiences and comments online and are able to interact with one another through social commerce, i.e., using online forums, reviews, recommendations and ratings (Chen et al. 2011; Hajli 2014; Liu, Lee, Liu, \& Chen, 2018; Ridings \& Gefen 2004). Research shows that social media usage leads to increased brand trust and intention to buy, through the increased social interactions of consumers (Hajli, 2014). Liu et al. (2018) reported that trust in consumers on a brand's social media site influences brand trust. Chen and Cheng (2019) found that media trust influenced consumers' diagnosis of fake news about a brand on social media and subsequent brand trust.

Scholars have also discussed the impact of the digital age on brand trust and brand management. Quinton (2013) argues that a new paradigm for brand management is needed in the digital era. The new paradigm should consider a changed power balance between brands and consumers, acknowledge and respect the online brand community, understand and embrace content co-creation by consumers, and the need for new types of knowledge such as 
broader intake of information to assist the development of brand management. To enhance brand trust, companies should consider both online and offline environments to reflect the new marketplace in the digital age (Kapferer, 2008; Keller, Aperia, \& Georgson, 2008).

Furthermore, Steenkamp (2020) argues that the digital age has posed new challenges for companies to build global brands because of "the rise of digital global distribution channels, transparency of a global brand's activities, global connectivity among brand consumers, and the Internet of things." (p. 24). Therefore, brand trust in the digital age is dependent not only upon consumers' perceived brand value based on their personal brand usage but also on their interactions with other consumers in the online and globalized space.

\subsection{Media Brand Trust and Its Connection to Media Uses \& Gratifications Theory}

Extending brand trust in marketing to the study of trust in media brands, there is a fundamental difference in the level of risk associated with media-consumption, because media audience typically pay none or a small fee to use social media platforms on which much content is compensated by third party advertisers. Because risk in media consumption is relatively small, the benefit-expectation dimension of brand trust will play a more important role in the formation of trust in social media brands. Therefore, this study defines brand trust in a social media environment as the audience's expectation of reliable media products in a limited risk environment. Trust in social media brands is much more complex than trust in a brand of tangible products, because it involves the trustworthiness of information flowing on 
the site, the security of financial transactions through the site, who collects user information, how the information is used, and much more (Pentina et al., 2013).

Research has found that trust in other users, similarity in personality traits with other users and electronic word-of-mouth (e-WOM) in the online community might all influence trust in a social media brand (Hajli, 2014; Liu et al., 2018; Pentina, Zhang \& Basmanova, 2013). For example, Liu et al. (2018) found that trust in other consumers in social media brand community can transfer into consumers' brand trust, and that consumers' engagement in the social media brand community will also promote their trust in the brand. Pentina et al. (2013) found that similarity in personality traits between Twitter users could engender users' trust in the Twitter platform. Ebrahim (2020) reported that e-WOM among users on social media has a significant positive effect on brand trust, suggesting that trust in other users' evaluation of a brand will promote one's own trust in the brand. Seo, Park and Choi (2020) reported that e-WOM among users had significant effects on brand awareness and trust of airline social media.

In exploring the determinants of social media brand trust, we take a utility-based approach and focus on perceived media values among social media users, because marketing research demonstrates the influence of brand value on brand trust as mentioned previously. Although perceived media values can be different from perceived brand values as the monetary cost of social media platforms is nearly zero and the types of utility that media bring to consumers could be completely different from tangible goods and products, there are 
similarities between perceived media values and perceived brand values. As previously noted, perceived brand values include functional, social, personal, and emotional values

(Kantamneini \& Coulson, 1996; Keller, 2008; Petrick, 2002; Sweeney \& Soutar, 2001), and media use can also fulfill different needs of users and have different values to media users.

Scholars in communication studies argue that perceived media values are primarily based on consumers' needs and motivation of media usage (Chen, 2017). Katz, Blumler, and Gurevitch, (1973)'s seminal work on media uses and gratifications identified 35 needs for using media, which were grouped into 5 categories: cognitive needs to strengthen information, knowledge, and understanding; affective needs to strengthen pleasurable and emotional experience; personal integrative needs to strengthen credibility, confidence, and status; social integrative needs to strengthen contact with family, friends, and the world; and needs to escape or to release tension.

The various needs of using media are parallel with perceived brand values mentioned previously. For instance, cognitive needs are similar to functional value of a brand (i.e., the utility derived from the perceived quality and expected performance of the product) because media are used for its information utility; social integrative needs is aligned with social value of a brand (i.e., the utility derived from the product's ability to enhance social self-concept) because media are used to enhance a person's social integration with others; personal integrative needs reflect personal value (i.e., an expression of consumers' self-fulfillment needs) because media are used for strengthen a person's confidence, status, and self-fulfillment; 
and affective needs and tension-release needs are in line with emotional value (i.e., the utility derived from the feelings or affective states that a product generates) because media are used for pleasure and tension release.

\subsection{How Social Media Uses and Gratifications Affect Social Media Brand Trust}

In the social media era, needs for social media use are becoming more and more diversified because communication between audience and media has become a two-way street and media audience has become active contributors of social media content instead of merely passively receiving messages (Chen et al., 2011; Falco \& Kleinhans 2018; Hajli, 2014). As a result, social media platforms become a place to reflect individual users' personal experience, emotions, social life, world views, political attitudes and more (Cuello-Garcia, Pérez-Gaxiola \& van Amelsvoort, 2020; Hunt et. al., 2012; Khan, 2017; Kim \& Kim, 2019; Krause et. al., 2014; Lisha et. al., 2017; Quan-Haase \& Young, 2010; Smock et al., 2011). Scholars have explored motivations of social media usage, and their research suggested that traditional media use motives such as information, entertainment, passing time, social interaction, and companionship contribute to social media usage; additionally, other factors such as giving information (Khan, 2017), sharing problems (Quan-Haase \& Young, 2010), self-expression (Hunt et al., 2012), seeking self-status (Khan, 2017), professional development, cool, and new trend (Smock et al., 2011) have also motivated the use of social media . Researchers in China have revealed similar findings (e.g.,Gan, 2017); moreover, the use of social media for mobile 
payment, e-commerce and communicating with governments is popular among Chinese citizens (He, 2020; Wang, 2016).

Given that various needs for media use and gratifications are parallel with perceived brand values, and that perceived brand values predict brand trust, we propose that the multidimensional needs of social media usage, or perceived media values, predict trust in social media brands. To the best of our knowledge, no studies have examined the link between social media uses and gratifications and trust in social media brands, especially in the context of social media use in China. Dwivedi et al. (2017) explicitly explored determinants of trust in social media brands and found that users' emotional attachment with a social media brand has an indirect influence on brand credibility. Specifically, if social media users like a certain social media brand, feel connected to the platform, and are passionate about it, they tend to have higher levels of trust in the brand. In addition, because increased social interactions in online communities through social media platforms can lead to increased brand trust and purchase intention (Hajli 2014; Liu et al., 2018), it is plausible that the formation of and interaction in online communities may have an impact on social media brand trust as well. However, there is scant research on social media brand trust and our research aims to connect social media uses to social media brand trust in China and propose the following hypotheses:

H1: Using social media for information seeking (i.e., perceived information value) is positively related to social media brand trust. 
H2: Using social media for entertainment (i.e., perceived entertainment value) is positively related to social media brand trust.

H3: Using social media for social networking (i.e., perceived social networking value) is positively related to social media brand trust.

H4: Using social media for seeking social status (i.e., perceived social-status-enhancing value) is positively related to social media brand trust.

H5: Using social media for communicating with government and organizations (i.e., perceived organizational communication value) is positively related to social media brand trust.

\subsection{Links Between Various Social Media Uses and Their Impact on Social Media Brand}

\section{Trust}

We also aim to examine how various social media uses influence one another and thus affect social media brand trust. Previous studies have not differentiated lower levels and higher levels of media usage needs and we propose two levels of needs for using social media. The first level includes using social media to seek for information and using social media to communicate with governmental agencies and other organizations, both of which are information-oriented. Using social media for information can be defined as "individuals' understanding of relevant events and conditions in the world around" and includes “information seeking, information sharing, obtaining communicatory utility, gaining social information, surveillance (i.e., knowledge about others), and self-documentation (i.e., 
lifelogging)" (Buzeta, Pelsmacker, \& Dens, 2020, p. 81). Information gathered from the media can help individuals surveil their environment and therefore affects their sense of security and safety (Dziekan \& Kottenhoff, 2007; KhajeNoori, \& Kaveh, 2013).

In China, many governmental agencies and organizations have their official social media accounts, through which they can disseminate information to their members to keep them informed. It is essential for citizens to use social media to keep themselves informed with governmental policies and decisions and to obtain information pertinent to daily life activities and welfare. Grassroot governments in China have often used the social media application WeChat to disseminate information to their residents. During COVID-19, WeChat became an important tool for local governments to deliver important information on lockdown and quarantine rules at the beginning, and later on grocery dropping off and distribution services. Individuals can also use social media to directly communicate with organizations to seek more information about their product or service. For instance, Nio (a Chinese electric vehicle maker) has its own social media application, called Nio Pilot, to communicate with its customers to understand their customers' real needs and feedback of company products. Nio Pilot attracted over 1 million users and they use Nio Pilot to obtain important product information (Zhang, 2021). Wang, Zhang, Luo, and Wang (2019) found that although the use of social media by Chinese non-profit organizations was not popular, but they used social media for various purposes, including communication, image building and fundraising. 
The second level of needs, we argue, include using social media for entertainment, using social media for social networking and using social media for social status, which are more emotion-oriented. Using social media for entertainment is defined as using social media for temporary emotional relief from daily routines and includes "escaping or being diverted from problems or routine; emotional release or relief; relaxation, cultural or aesthetic enjoyment; passing time, having fun, and playing” (Buzeta, Pelsmacker, \& Dens, 2020, p. 81). Using social media for social networking is defined as "the users' feeling of connection (to an online community, for instance) that enables them to increase their knowledge about other people's circumstances and augment individuals' socializing capabilities" and includes "the sense of belonging (e.g., connectedness), the supportive peer groups (e.g., bandwagon), and the enhanced interpersonal connections associated with media usage (e.g., community building)" (Buzeta, Pelsmacker, \& Dens, 2020, p. 81). When using social media to seek for social status, users desire for personal dignity and reputation or respect from others (e.g., status and prestige), because using social media for social status refers to sharing content and ideas on social media to gain the reputation and popularity on social media and thus the feeling of being important and being admired by others (Lee \& Ma, 2012). It is evident that using social media for entertainment, social networking and social status are all emotionally bound.

According to Bartsch and Viehoff (2010) in their study of media entertainment, "emotions are the results of cognitive appraisal processes" (p. 2251) because when people evaluate situations and information regarding personal goals, needs, and desires, it often results 
in emotional reaction. Pessoa (2008) reviewed research on the relationship between cognition and emotion and contended that cognition and emotion are integrated in the brain.

Traditionally, an individual's cognition is a key determinant of his or her emotion (Schachter and Singer, 1962) and conscious or unconscious appraisal of events and information involves emotion (Arnold, 1960). Therefore, we argue that information-oriented social media uses (i.e., using social media for information and using social media for organizational communication) can influence a person's use of social media for entertainment, social networking and social status. Below we develop our theoretical arguments for each of the possible interconnected relationships, respectively.

First, we argue that when a person uses social media to seek information, such information can also be entertaining because certain information can provide enjoyment, help individuals relax or pass time. Research suggested that using media for entertainment is often motivated by users' desire. For instance, bored individuals tend to seek for arousing media content and information, but stressed users tend to seek for soothing media content and information (Bartsch \& Viehoff, 2010). Users' cognition and emotions are integrated in the brain, and emotion is involved in individuals' evaluation of events and situations (Arnold, 1960; Bartsch \& Viehoff, 2010; Pessoa, 2008). Suckfüll's research (2004) examined various kinds of involvement in film viewing and showed that emotional involvement correlated with various types of involvement in reception, especially when viewers are absorbed in the fictional world, identify with characters, and relate the film to their own lives. These research 
findings suggest that using social media for information may be related to using social media for entertainment, which can subsequently influence social media brand trust. Therefore, we propose the following hypothesis:

H6: Using social media for information (i.e., perceived information value) is associated with using social media for entertainment, which subsequently influences trust in social media brands.

Second, using social media for information is inherently related to and beneficial for social networking as information exchange and communication is a necessity for interpersonal connections (Buzeta, Pelsmacker, \& Dens, 2020). Social networking requires users to gain knowledge about other members of the group and therefore information is a necessary step. For instance, when individuals join an online support group for depression such as 7 cups, they seek for information on the cause, symptoms, treatment and counseling services for depression. It is also possible that individuals discover and join such support groups when they try to seek information about depression online. Therefore, using social media for information can be beneficial for one's social networking on social media. Based on this proposition, we develop the following hypothesis:

H7: Using social media for information (i.e., perceived information value) is associated with using social media for social networking, which subsequently influences trust in social media brands. 
Third, it is plausible that using social media for information is related to using social media for social status. Vogel, Rose, Roberts and Eckles (2014) reported that social media information (such as social network activity level and healthy habits) induced either upward or downward social comparison, therefore influencing an individual's self-evaluation and social status assessment. Specifically, Facebook users exposed to upward social comparison information on the site most often had a lower level of self-esteem, and their self-evaluation was lower after exposure to upward comparison information (e.g., a high activity social network, healthy habits) than exposure to downward comparison information (e.g., a low activity social network, unhealthy habits). Therefore, it is plausible that using social media for information can be linked to using social media for social status, because information gathered from social media can be used for a person's self-evaluation of his or her social status.

Consequently, we propose the following hypothesis:

H8: Using social media for information (i.e., perceived information value) is associated with using social media for social status, which subsequently influences trust in social media brands.

Fourth, we argue that using social media to communicate with government or other organizations is associated with using social media for social networking. Using social media for organizational communication is an interesting yet important function of social media in public relations (Bordeianu, 2012). Social media have become an important venue for individual users to connect with various organizations and this type of social media use is 
conducive to social networking among an organization's customers. For instance, when individuals use WeChat groups to communicate with governmental agencies, they may come across with like-mind citizens or citizens in similar situations. It is easy for them to network with one another based on their shared interests.

Another example is using social media to communicate with other organizations such as for-profit corporations. Nio users use Nio Pilot, a social media platform created by Nio, to communicate with the company initially, but gradually they formed a robust social network among themselves. By using Nio Pilot, customers formed Nio car owners' associations across the country, and they even networked with one another and organized an annual summit for Nio (Yang, 2021). When individuals use social media to communicate with an organization, it will help build a broad social network in which a homogenous group of people form a community with shared interests and values. Therefore, we propose the following hypothesis:

H9: Using social media for communicating with organizations (i.e., perceived organizational communication value) is associated with using social media for social networking, which subsequently influences trust in social media brands.

Fifth, we argue that using social media to communicate with organizations is related to using social media for social status. Boyd and Ellison (2007) contend that social media sites often facilitate the formation and development of homogenous groups that share some characteristics (e.g., race and religion). Khang, Han, and Ki (2014) reported that social media usage had a significant relationship with a person's expected social status outcome. 
Engagement with established organizations (governments or corporations) through social media will give users fulfillment and feelings that they are important, or that their opinions matter, which will in turn promote the perception of one's social status. For example, because Nio car owners and app users tend to be wealthy individuals who care more about service quality, joining the corporation's online user community not only enhances users' feelings of self-importance and belongingness but also facilitates the identification of their own social status and social identity. As a result, we propose the following hypothesis:

H10: Using social media for communicating with organizations (i.e., perceived organizational communication value) is associated with using social media for social status, which subsequently influences trust in social media brands.

[Insert Figure 1 about here.]

\section{Methods}

\subsection{Survey Procedure and Participants}

To test the hypotheses, we conducted an original survey through two channels: paper-and-pencil questionnaires and electronic questionnaires. The paper-and-pencil questionnaires were distributed to a sample of college students at a university in Guangdong Province, China, including undergraduate seniors and graduate students. A total of 225 questionnaires were collected, of which 209 were valid. ${ }^{2}$ In order to increase the diversity of participants, we hired a research organization (www.wjx.cn) to collect more responses from

\footnotetext{
${ }^{2}$ Questionnaires with missing questions or with the same answer throughout the questionnaire were considered as invalid questionnaires and are excluded from the sample.
} 
non-student respondents outside of Guangdong province. The e-version of the questionnaire had a screening question, "What is your occupation?" and the survey would end if the respondent identifies himself/herself as a student. A total of 332 responses with different IP addresses from outside of Guangdong province were obtained and 318 of them were valid. Combining the two sources, we were able to obtain 527 responses. The sample has a similar gender and age composition (Table 1) with the general social media user community in China based on the latest Chinese social media users survey (IResearch, 2019).

[Insert Table 1 about here].

\subsection{Survey Questionnaire}

\subsubsection{Social media uses and gratifications}

Adapting from previous research on social media uses and gratifications (Hunt et. al., 2012; Khan, 2017; Kim \& Kim, 2019; Krause et. al., 2014; Lisha et. al., 2017; Papacharissi \& Rubin, 2000; Quan-Haase \& Young, 2010; Smock et al., 2011), we measured various uses and gratifications of social media through 15 items (see Table 2). ${ }^{3}$ Participants were asked to indicate what social media sites they use most often and rate their agreement with each statement about why they use social media on a seven-point Likert scale $(1=$ strongly disagree and $7=$ strongly agree .

For the 15 items, we conducted an exploratory principal component factor analysis that yielded five factors with eigenvalues greater than 1 , including using social media for

\footnotetext{
3 The 15-item scale was developed based on an exploratory factor analysis of a 29-item scale with a sample of 302 participants, which produced 5 factors. More details are available from the authors upon request.
} 
information, entertainment, social networking, seeking social status, and communication with government and organizations. The total variance explained by the five factors was $66.11 \%$. Table 2 shows items used for each dimension of social media use and corresponding factor loadings. A confirmatory principle component factor analysis with varimax rotation showed that for each latent variable, all factor loadings were satisfactory (Table 2). The composite reliability was greater than 0.8 , confirming that the internal consistency of the constructs (Table 3) (Fornell \& Larcker, 1981). The scale's convergence validity and discriminant validity were satisfactory (Table 3). All average variance extracted (AVE) values were greater than 0.50, indicating that the scale had a good convergence validity (Chin, 1988; Fornell \& Larcker, 1981). The square root of each dimension's AVE value was greater than the correlation coefficients between the dimension and other dimensions (the diagonal line in

Table 3), indicating that the scale had a very good discriminant validity (Fornell \& Larcker, 1981).

[Insert Table 2 about here].

[Insert Table 3 about here].

\subsubsection{Social media brand trust}

Adapting from Chaudhuri and Holbrook (2001)'s brand trust scale we measured trust in social media brands with three items on a 7 -point Likert scale $(1=$ strongly disagree, $7=$ strongly agree): "I trust this social media brand," "I have confidence in this social media brand," and "this social media brand never disappoints me." The scale's Cronbach $\alpha$ was 0.714 and the 
items were averaged to form a composite index of social media brand trust $(M=5.75, S D$ $=0.03)$.

\section{Results}

\subsection{Results of the Original SEM Model}

Before we performed a structural equation modeling analysis, we used SPSS to perform both Kolmogorov-Smirnov tests on the normality of variables, and results showed that the assumption of normal distribution was not met. Therefore, we performed a partial least squares structural equation modeling (PLS-SEM) analysis by using SmartPLS3.0 (Wang, Chen \& Solheim, 2020) to test our hypotheses H1-H10.

Overall, the explained variance $\left(\mathrm{R}^{2}\right)$ of each endogenous variable in the model (i.e., entertainment value, social networking value, social status value, and social media brand trust) ranged from 0.12 to 0.37 , larger than the threshold value of 0.10 (Falk \& Miller, 1992), therefore, the model specification was satisfactory based on this benchmark (see Table 4). Moreover, the predictive relevance $\left(\mathrm{Q}^{2}\right)$ of each of the endogenous variables ranged from 0.08 to 0.23 (see Table 4), larger than the threshold value of 0.02 (Hair, Ringle, \& Sarstedt, 2013), indicating a satisfactory model overall.

After the evaluation of the overall model, we examined the results of path analyses and mediation effect analyses based on bootstrapping $(n=1000)$. Results showed that using social media for entertainment $\left(~\left(=0.25, \mathrm{SD}=0.04, p<0.001\right.\right.$; effect size $\left.\mathrm{f}^{2}=0.08\right)$, social networking $\left(ß=0.27, \mathrm{SD}=0.05, p<0.001 ;\right.$ effect size $\left.\mathrm{f}^{2}=0.10\right)$, and social status $(\beta=0.25, \mathrm{SD}=0.04, p$ 
$<0.001$; effect size $\mathrm{f}^{2}=0.08$ ) were positively related to trust in social media brands. In other words, people perceived a higher level of entertainment value, social networking value, or social-status value of social media trusted social media brands more. Therefore, H2, H3 and H4 were supported. However, using social media either for information $(B=0.11, \mathrm{SD}=0.05, p<$ 0.05 , effect size $\left.\mathrm{f}^{2}=0.01\right)^{4}$ or for communication with government and organizations $(~ B=0.06$, $\mathrm{SD}=0.04, p>0.05$; effect size $\mathrm{f}^{2}=0.01$ ) was not significantly related to trust in social media. Therefore, H1 and H5 were not supported.

Regarding the indirect effects of using social media for information on brand trust through the mediation of using social media for entertainment, social networking and social status (H6, $\mathrm{H} 7$, and $\mathrm{H} 8$, respectively), results showed that using social media for information was positively associated with using social media for entertainment $(\beta=0.41, S D=0.05, p<0.001$; effect size $\mathrm{f}^{2}=0.21$, which subsequently was positively related with social media brand trust. The mediation test showed that the mediation was significant, $\beta=0.10, S D=0.02, p<0.001$. Therefore, H6 was supported.

Similarly, results showed that using social media for information was positively related to using social media for social networking $\left(\beta=0.26, \mathrm{SD}=0.07, \mathrm{p}<0.001\right.$; effect size $\left.\mathrm{f}^{2}=0.07\right)$, which was positively related to trust in social media brands. The mediation test showed that the mediation was significant, $\beta=0.07, \mathrm{SD}=0.02, \mathrm{p}<0.001$ ). Therefore, $\mathrm{H} 7$ was supported.

\footnotetext{
${ }^{4}$ Despite $\mathrm{p}<0.05$, according to Cohen (1988), an effect size $\left(\mathrm{f}^{2}\right)$ smaller than 0.02 is not statistically significant.
} 
As for $\mathrm{H} 8$, results showed that perceived information value of social media was not significantly associated with perceived social status value of social media ( $(3=0.07, \mathrm{SD}=0.07$, $\mathrm{p}=0.16$; effect size $\mathrm{f}^{2}=0.01$ ); in the meantime, the mediation test showed that perceived social status value of social media did not mediate the effect of perceived information value on trust in social media brands $(B=0.02, \mathrm{SD}=0.01, \mathrm{p}=0.20)$. Therefore, $\mathrm{H} 8$ was not supported by the data.

As for $\mathrm{H} 9$, results showed that perceived organizational communication value of social media was significantly related to perceived social networking value of social media, $\beta=0.19$, $\mathrm{SD}=0.05, \mathrm{p}<0.001 ;$ effect size $\left.\mathrm{f}^{2}=0.04\right)$. Meanwhile, perceived social networking value of social media significantly mediated the effect of perceived organizational communication value of social media on trust in social media brands $(\beta=0.05, \mathrm{SD}=0.02, \mathrm{p}<0.05)$. Therefore, H9 was supported.

Regarding H10, results showed that perceived organizational communication value of social media was significantly related to perceived social-status value of social media ( $\beta$ $=0.32, \mathrm{SD}=0.05, \mathrm{p}<0.001 ;$ effect size $\left.\mathrm{f}^{2}=0.10\right)$, and perceived social status value of social media mediated the effect of perceived organizational communication value of social media on trust in social media brands $(\beta=0.08, \mathrm{SD}=0.02, \mathrm{p}<0.001)$. Therefore, $\mathrm{H} 10$ was supported.

[Insert Figure 2 about here.]

\subsection{Model Modification}


We dropped the non-significant paths to simplify the model, including the paths associated with $\mathrm{H} 1, \mathrm{H} 5$ and $\mathrm{H} 8$. The overall model indices showed that the $\mathrm{R}^{2}$ values were between 0.12 and 0.36 (larger than the threshold value of 0.10, Falk \& Miller, 1992) and the $Q^{2}$ values were between 0.08 and 0.22 (larger than the threshold value of 0.02 , Hair et al., 2013), indicating an overall fit model. Figure 3 shows the final model.

[Insert Figure 3 about here.]

\section{Discussion}

\subsection{Implications of Results}

While more and more people use social media daily and spend tremendous amount of time on social media, a survey of more than 80,000 people in 40 countries before the COVID-19 pandemic revealed low levels of trust in digital news and rising concern about misinformation online, despite the efforts made by journalists, editors, politicians, and public health officials to convey truthful messages to the general public (Newman, Fletcher, Schulz, Andi, \& Neilsen, 2020). Against this backdrop, our study aims to answer an important question: What influences trust in social media brands? We borrow literature from both marketing and media to examine how various uses of social media (i.e., perceived media values) influence trust in social media brands.

First and foremost, we find that perceived social media's entertainment value, social networking value, and social status value are all positively related with trust in social media brands. These results echo the literature that perceived brand values influence brand trust 
(Chaudhuri \& Holbrook, 2001; Chi, Yeh, \& Chiou, 2009; Ercis, 2012; Harris \& Goode, 2004; Moliner, 2009; Prameka et al., 2016; Zohaib \& Muhammad, 2014) and demonstrate that social media platforms and brands are similar to regular product brands like MacDonald, Nike, and Apple because these social media brands can also provide functional, emotional, social, and personal values and satisfy consumers' needs at various levels, which can lead to increased trust in social media brands. To our knowledge, previous studies have not linked various social media uses to trust in social media brands, and our research fills this gap. A study found that people trusted news posted on Facebook more when their real-life friends acted as opinion leaders and shared the news on social media (Turcotte, York, Irving, Scholl, \& Pingree, 2015). Ayaburi and Treku (2020) surveyed Facebook users and showed that users' perceptions of the alignment between the social media brand's (i.e., Facebook) words in an apology and subsequent actions impacted users' trust in Facebook and allied services such as Instagram. Our research extends this line of research and shows that trust in social media brands is connected with fundamental values of social media such as providing entertainment, expanding social network and boosting social status. These findings imply that social media brands could optimize their entertainment content, social networking function, and social-status-enhancing function to increase their users' trust in their brands and thus attract more users and increase traffic. The direct connection between perceived entertainment value of social media and trust in social media brands may explain why multiple channel networks 
that position entertainment as its core content have gained much development over recent years amid increased heated competition among social media platforms.

Our study also shows that although perceived social media's information value and organizational communication value do not have direct effects on trust in social media brands, they have indirect effects through the mediation of perceived entertainment value and social networking value. An explanation for this is that information provided by social media is intertwined with entertainment and provides entertainment to users at the same time. Similarly, information gained from social media allows people to follow their friends, celebrity figures, and other favorite social media accounts, thus providing a broad range of conversation topics and facilitating users' interactions with others. This may explain why Chinese social media platforms recruit many opinion leaders to interact with their users - the blend of interpersonal communication with information seeking on social media increases social media brand trust and boosts user attachment to social media platforms. For example, many bloggers interact with their fans on Weibo (the Chinese version of Twitter) and the para-social interaction on Weibo coupled with information gained from these opinion leaders have attracted more and more users, thus making Weibo a popular social media brand in China. We also think the indirect effect of perceived information value on brand trust in part reflects the disconnection between the increasing dependence on social media and brand trust. Although social media platforms provide tailored content to their users based on their algorithm and users spend more 
and more time on social media to gain information, users do not necessarily trust social media brands more.

In China, many local and provincial governments try to better connect with citizens through various social media apps on social media provide communication channels between ordinary citizens and the governments. Ordinary citizens often use social media to submit their complaints about corruption and other issues; therefore, it is plausible that using social media to communicate with local and provincial governments does not directly affect trust in social media brands. Moreover, using social media to communicate with governments and organizations helps expand a person's social network, but this type of ties is weaker than ties with family, friends, and coworkers on social media, which does not necessarily directly increase individuals' trust in social media brands. Another reason may lie in the fact that in the process of communicating with governments and other organizations, personal identification information is required and therefore it is less likely to find a direct connection between using social media to communicate with governments and corporations and trust in social media brands. However, using social media for organizational communication has indirect effects on social media brand trust through the mediation of using social media for social networking and seeking social status, which is especially true when individuals use companies' own social media apps (e.g., Nio's own user app). By using a certain brand and its products, the brand's customers form a homogenous group that have certain social identities in various aspects such as age, socioeconomic status and lifestyles. Then the brand's customers form an online social 
network through the use of the company's social media app, in which social ties are more interactive and stronger than the offline social network and the group's social status is strengthened and becomes more prominent. Our study demonstrates that these types of social media uses increase social media brand trust.

\subsection{Limitations and Future Research}

The current research is based on a cross-sectional survey, therefore the direct and indirect effects of perceived media values on social media brand trust are only correlational, not causal relationships. Second, despite the study's participants were largely consistent with the general social media user community in China (IResearch, 2019), the study's participants have an average age of 33 and therefore may use social media more than the general public; as a result, whether the relationships reported in the current research are applicable to other populations needs further testing. Another limitation is that when we measured various uses of social media in Chinese, most of the items were focused on users' attitudes toward the platform or potential outcomes of social media use (e.g., "This social media platform can help me gain useful information." ) but a few were focused on reported behaviors or outcomes that have already occured (e.g., "This social media platform has increased the connection between me and my friends.”). The inconsistency in these items was not optimal and future surveys should use consistently worded questions. Nonetheless, we would like to point out that despite this subtle difference, each social media use scale has a high reliability.

Despite the limitations, we believe that the current study has significant contributions as it disentangles the relationships between various perceived media values and social media brand 
trust and has important practical implications for the development of social media platforms and how to increase social media users' trust in social media. Future research is needed to test the relationships between perceived social media values and trust in social media brands in a different sample, preferably an older sample of participants. Second, the current study examines the relationships without focusing on specific social media brands, and future research can be directed to focusing on top Chinese social media brands, such as WeChat, QQ, Weibo, and others. 


\section{References}

Arnold, M. B. (1960). Emotion and personality. Columbia University Press, New York.

Ayaburi, E. W., \& Treku, D. N. (2020). Effect of penitence on social media trust and privacy concerns: The case of Facebook. International Journal of Information Management, 50, 171-181. https://doi.org/10.1016/j.ijinfomgt.2019.05.014.

Bagozzi, R. P., \& Yi, Y. (1988). On the evaluation of structural equation models. Journal of the Academy of Marketing Science, 16(1), 74-94.

Barnes, S. J., \& Bohringer, M. (2011). Modeling use continuance behavior in microblogging services: The case of Twitter. Journal of Computer Information Systems, 51 (4), 1-10.

Bartsch, A., \& Viehoff, R. (2010). The use of media entertainment and emotional gratification. Procedia-Social and Behavioral Sciences, 5, 2247-2255.

Bhattacharya, R. , Devinney, T. M. \& Pillutla, M. M. (1998). A formal model of trust based on outcomes. Academy of Management Review, 23(3), 459-472.

Blackston, M. (1992). A Brand with an Attitude: A Suitable Case for the Treatment. Journal of the Market Research Society, 34(3), 231-241.

Boyd, D. M., \& Ellison, N. B. (2007). Social network sites: Definition, history, and scholarship. Journal of computer-mediated Communication, 13(1), 210-230. 
Buzeta, C., De Pelsmacker, P., \& Dens, N. (2020). Motivations to use different social media types and their impact on consumers' online brand-related activities (COBRAs). Journal of Interactive Marketing, 52, 79-98.

Chaudhuri, A., Holbrook, M. B. (2001). The chain of effects from brand trust and brand affect to brand performance: the role of brand loyalty. Journal of Marketing, 65(2), 81-93.

Chen, Y.-R. R. (2017). Perceived values of branded mobile media, consumer engagement, business-consumer relationship quality and purchase intention: A study of WeChat in China. Public Relations Review, 43(5), 945-954.

Chen, Z. F., \& Cheng, Y. (2019). Consumer response to fake news about brands on social media: the effects of self-efficacy, media trust, and persuasion knowledge on brand trust. Journal of Product \& Brand Management.

Chi, H. K. , Yeh, H. R., \& Chiou, C. Y. (2009). The Effects of Brand Effect on Female Cosmetic Users Brand Loyalty in Taiwan.Journal of American Academy of Business, 14(2),230-236.

Chin, W. W. (1998). Issues and opinion on structural equation modeling. MIS Quarterly, 22(1), $1-18$.

Cohen, J. (1988). Statistical power analysis for the behavioral sciences ( $2^{\text {nd }}$ ed.). Mahwah:

Cuello-Garcia, C., Pérez-Gaxiola, G., \& van Amelsvoort, L. (2020). Social media can have an impact on how we manage and investigate the COVID-19 pandemic. Journal of Clinical Epidemiology, 127, 198. 
Delgado-Ballester,E., Munuera-Alemán,J. L., \& Yague-Guillen, M. J. (2003). Development and validation of a brand trust scale. International Journal of Market Research, 45 (1), $35-54$.

Delgado-Ballester, Elena, \& Munuera-Alemán, J. L. . (2005). Does brand trust matter to brand equity?. Journal of Product \& Brand Management, 14 (3), 187-196.

Dwyer, C., Hiltz, S. R. \& Passerini, K. (2007). Trust and privacy concern within social networking sites: A comparison of Facebook and Myspace. In Proceedings of $13^{\text {th }}$ Americas' conference on information systems Keystone, CO.

Dziekan, K., \& Kottenhoff, K. (2007). Dynamic at-stop real-time information displays for public transport: effects on customers. Transportation Research Part A: Policy and Practice, 41(6), 489-501.

Dwivedi, A., Johnson, L. W., Wilkie, D. C., \& De Araujo-Gil, L. (2019). Consumer emotional brand attachment with social media brands and social media brand equity. European Journal of Marketing.

Ebrahim, R. S. (2020). The role of trust in understanding the impact of social media marketing on brand equity and brand loyalty, Journal of Relationship Marketing,19, 287-308, DOI: 10.1080/15332667.2019.1705742

Ercis, A. , ünal, S., Candan, F. B., \& Yildirim, H. (2012). The effect of brand satisfaction, trust and brand commitment on loyalty and repurchase intentions. Procedia-Social and Behavioral Sciences, 58, 1395-1404. 
Falco, E., \& Kleinhans, R. (2018). Beyond information-sharing. a typology of government challenges and requirements for two-way social media communication with citizens. Electronic Journal of e-Government, 16(1), pp32-45.

Falk, R. F., \& Miller, N. B. (1992). A primer for soft modeling. University of Akron Press.

Fornell, C. , \& Larcker, D. F. (1981). Evaluating structural equation models with unobservable variables and measurement error. Journal of Marketing Research, 18(1), 39-50.

Gan, C. (2017). A study on the uses and gratifications of social media. Library Information, 11, 106-115. 甘春梅. (2017). 社交媒体使用动机与功能使用的关系研究: 以微信 为例. 图书情报工作, 11, 106-115.

Garbarino, E. , \& Johnson, M. S. (1999). The different roles of satisfaction, trust, and commitment in customer relationships. Journal of Marketing, 63(2), 70-87.

Gil de Zúñiga, H., Jung, N., \& Valenzuela, S. (2012). Social media use for news and individuals' social capital, civic engagement and political participation. Journal of computer-mediated communication, 17(3), 319-336.

Gu, R., Oh, L-B., \& Wang, K. (2009). Determinants of customer loyalty for social networking sites. In Exploring the grand challenges for next generation E-Business (pp. 206-212).

Hair, J. F., Ringle, C. M., \& Sarstedt, M. (2013). Partial least squares structural equation modeling: Rigorous applications, better results and higher acceptance. Long range planning, 46(1-2), 1-12. 
Hajli, M. N. (2014). A study of the impact of social media on consumers. International journal of market research, 56(3), 387-404.

Harris, L. C. , \& Goode, M. M. H. (2004). The four levels of loyalty and the pivotal role of trust: a study of online service dynamics. Journal of Retailing, 80( 2), 139-158.

He, X., Luo, S., \& Huang, K. (2020). A study on the motives of WeChat group users' participation in the discussion of public emergencies. Intelligence Quest, 7, 13-20. 何晓兵,罗硕,黄楷胤. (2020). 微信群用户参与公共突发事件话题讨论的动机研究. 情报探索,07, 13-20.

Hunt, D. , Atkin, D. , \& Krishnan, A. (2012). The influence of computer-mediated communication apprehension on motives for Facebook use. Journal of Broadcasting \& Electronic Media, 56(2), 187-202.

Iqbal, Mansoor. 2021. WeChat Revenue and Usage Statistics. Business of Apps. Retrieved from https://www.businessofapps.com/data/wechat-statistics/

Iresearch (2019), China Internet Social Media Enterprise Marketing Strategy White Paper, Retrieved from http://report.iresearch.cn/report/201912/3509.shtml

Kantamneni S. P. ,\& Coulson K. R. (1996). Measuring perceived value: Scale development and research findings from a consumer survey. Journal of Marketing Management, 6(2), 72-86.

Kapferer, J.-N. (2008). The new strategic brand management. London: Kogan Page. 
Katz E. , Blumler J. G. , \& Gurevitch, H. M. (1973). Uses and gratifications research. Public Opinion Quarterly, 37(4), 509-523.

Keller, K. L. (2008). Strategic brand management : Building, measuring, and managing brand equity. New Jersey: Pearson Education Inc.

Keller, K.L., Aperia, T., \& Georgson, M. (2008). Strategic brand management. Harlow, England: FT Prentice Hall.

Khan, M. L. (2017). Social media engagement: what motivates user participation and consumption on YouTube?. Computers in Human Behavior, 66, 236-247.

Khang, H., Han, E-K., Ki, E-J (2014). Exploring influential social cognitive determinants of social media use. Computers in Human Behavior, 36, 48-55, https://doi.org/10.1016/j.chb.2014.03.038.

KhajeNoori, B., \& Kaveh, M. (2013). A Study of the Relationship between Media Consumption and Feeling of Social Security. Security and Social Order Strategic Studies Journal, 6(2), 15-17.

Kim, B. , \& Kim, Y. (2019). Facebook versus Instagram: how perceived gratifications and technological attributes are related to the change in social media usage. Social Science Journal, 56(2), 156-167.

Krause, A. E. , North, A. C. , \& Heritage, B. (2014). The uses and gratifications of using Facebook music listening applications. Computers in Human Behavior, 39, 71-77. 
Laroche, M. , Habibi, M. R. , Richard, M. O. , \& Sankaranarayanan, R. (2012). The effects of social media based brand communities on brand community markers, value creation practices, brand trust and brand loyalty. Computers in Human Behavior, 28(5), $1755-1767$.

Lau, G. T. , \& Lee, S. H. (1999). Consumers' trust in a brand and the link to brand loyalty. Journal of Market Focused Management, 4(4), 341-370.

Lee, C. S., \& Ma, L. (2012). News sharing in social media: The effect of gratifications and prior experience. Computers in Human Behavior, 28 (2), 331-339. https://doi.org/10.1016/j.chb.2011.10.002.

Lisha, C. , Goh, C. F. , Yifan, S. , \& Rash, A. (2017). Integrating guanxi into technology acceptance: an empirical investigation of WeChat. Telematics and Informatics, 34(7), $1125-1142$.

Liu, L., Lee, M. K., Liu, R., \& Chen, J. (2018). Trust transfer in social media brand communities: The role of consumer engagement. International Journal of Information Management, 41, 1-13.

Lumsden, J., \& MacKay, L. (2006). How does personality affect trust in B2C ecommerce? In Proceedings of $8^{\text {th }}$ international conference on electron.

McDonald, R. P., \& Ho, M. H. R. (2002). Principles and practice in reporting structural equation analyses. Psychological methods, 7(1), 64. 
Metzger, M. J. (2004). Privacy, trust, and disclosure: Exploring barriers to electronic commerce. Journal of Computer-Mediated Communication, 9(4).

Moliner, M. A. (2009). Loyalty, perceived value and relationship quality in healthcare services. International Journal of Service Industry Management, 20(1), 76-97.

Morgan, R. M. , \& Hunt, S. D. (1994). The commitment-trust theory of relationship marketing. Journal of Marketing, 58(3), 20-38.

Newman, N., Fletcher, R., Schulz, A., And1, S., \& Nielsen R. K. (2020). Reuters Digital News Report 2020. Retrieved from https://reutersinstitute.politics.ox.ac.uk/sites/default/files/2020-06/DNR_2020_FINA $\underline{\text { L.pdf }}$

Papacharissi, Z. , \& Rubin, A. M. (2000). Predictors of internet use. Journal of Broadcasting \& Electronic Media, 44(2), 175-196.

Park, N. , Kee, K. F. , \& Valenzuela, S. (2009). Being immersed in social networking environment: Facebook groups, uses and gratifications, and social outcomes. Cyberpsychology \& Behavior, 12(6), 729-733.

Pessoa, L. (2008). On the relationship between emotion and cognition. Nature reviews neuroscience, 9(2), 148-158.

Pelling, E. L., \& White, K. M. (2009). The theory of planned behavior applied to young people's use of social networking web sites. CyberPsychology and Behavior, 12 (6), $755-759$. 
Pentina, I., Zhang, L., \& Basmanova, O. (2013). Antecedents and consequences of trust in a social media brand: Across-cultural study of Twitter. Computers in Human Behavior, 29(4), 1546-1555.

Petrick, J. F. (2002). Development of a multi-dimensional scale for measuring the perceived value of a service. Journal of Leisure Research, 34(2), 119-134.

Pookulangara, S., \& Koesler, K. (2011). Cultural influence on consumers' usage of social networks and its' impact on online purchase intentions. Journal of Retailing and Consumer Services, 18 (4), 348-354.

Prameka, A. S. , Do, B. R. , \& Rofiq, A. (2016). How brand trust is influenced by perceived value and service quality: mediated by hotel customer satisfaction. Asia-Pacific Management and Business Application, 5, 73-88

PSRA (2002). A Matter of trust: What users want from web sites. Research Report. Retrieved from consumerreports.org on November 1, 2020 (https://advocacy.consumerreports.org/research/a-matter-of-trust-what-users-want-fro $\underline{\text { m-web-sites/) }}$

Quan-Haase, A. , \& Young, A. L. (2010). Uses and gratifications of social media: a comparison of facebook and instant messaging. Bulletin of Science, Technology \& Society, 30(5), 350-361. 
Quinton, S. (2013). The community brand paradigm: A response to brand management's dilemma in the digital era. Journal of marketing management, 29(7-8), 912-932.

Schachter, S. , \& Singer, J. (1962). Cognitive, social, and physiological determinants of emotional state. Psychological Review, 69(5), 379.

Sherman, A. (August 24, 2020). TikTok reveals detailed uer numbers for the first time. Consumer News and Business Channel (CNBC) online news. Retrieved from https://www.cnbc.com/2020/08/24/tiktok-reveals-us-global-user-growth-numbers-forfirst-time.html)

Sheth, J. N., Newman, B. I., \& Gross, B.L. (1991). Why we buy what we buy: A theory of consumption values. Journal of Business Research, 22(2), 159-170.

Smock, A. D., Ellison, N. B., Lampe, C., \& Wohn, D. Y. (2011). Facebook as a toolkit: a uses and gratification approach to unbundling feature use. Computers in Human Behavior, 27(6), 2322-2329.

Steenkamp, J. B. E. (2020). Global brand building and management in the digital age. Journal of International Marketing, 28(1), 13-27.

Sweeney, J. C., \& Soutar, G. N. (2001). Consumer perceived value: The development of a multiple item scale. Journal of Retailing, 77(2), 203-221.

Turcotte, J., York, C., Irving, J., Scholl, R. M., \& Pingree, R. J. (2015). News Recommendations from Social Media Opinion Leaders: Effects on Media Trust and Information 
Seeking, Journal of Computer-Mediated Communication, 20( 5),

520-535, https://doi.org/10.1111/jcc4.12127

Ulaga, W. , \& Eggert, A. (2006). Relationship value and relationship quality: broadening the nomological network of business-to-business relationships. European Journal of Marketing, 40(3/4), p.311-327.

Ulusu, Y., Durmus, E.S., \& Yurtkoru, D. (2011). Personality, privacy and trust issues in virtual society. In E. Centeno \& C. Veloutsou (Eds.), New perspective of contemporary marketing, Athens.

Vogel, E. A., Rose, J. P., Roberts, L. R., \& Eckles, K. (2014). Social comparison, social media, and self-esteem. Psychology of popular media culture, 3(4), 206.

Wang, R. , Chen, L. , Ayesh, A. , \& Solheim, I. . (2020). Modeling Dyslexic Students' Motivation for Enhanced Learning in E-learning Systems. ACM Transactions on Interactive Intelligent Systems, 11,p. 5-39.

Wang, W. (2016). An analysis of social media users' usage motivations and behaviors.

Journal of Hunan Normal University Social Science, 45, 155-160. 王玮. (2016). 社 会化媒体用户使用动机与行为探析. 湖南师范大学社会科学学报, 45(5), 155-160.

Wang, X. Li, F., Yu, W. (2010). How do they really help? An empirical study of the role of different information sources in building brand trust. Journal of Global Marketing, 23(3), p.243-252. 
Wang, X., Zhang, J., Luo, L., \& Wang, B. (2019). Chinese NPOs' social media use and impact measurement. Journal of Beijing University of Aeronautics and Astronautics Social Sciences Edition, 32(6): 59-68

Yang, L. (January 11, 2021). Why is Nio's user stickness so high? Retrieved from https://m.gasgoo.com/news/70237533.html

Zeithaml, V. A. (1988). Consumer perceptions of price, quality, and value: a means-end model and synthesis of evidence. Journal of Marketing, 52(3), 2-22.

Zhang, P. (May 31, 2021). With over 1.6 million registered users, NIO app is far from a vehicle management tool. Retrieved from https://cnevpost.com/2021/05/31/with-over-1-6-million-registered-users-nio-app-is-far$\underline{\text { from-a-vehicle-management-tool/ }}$

Zhu, J., \& Yang, Y. (2020). Exclusive: TikTok-owner ByteDance to rake in \$27 billion ad revenue by year-end: sources. Retrieved from

https://www.reuters.com/article/china-bytedance-revenue/exclusive-tiktok-owner -bytedance-to-rake-in-27-billion-ad-revenue-by-year-end-sources-idUSKBN27R $\underline{191}$

Zohaib, A. , Muhammad, R. , Mukhtar, A. , \& Misbahul, H. (2014). Effect of brand trust and customer satisfaction on brand loyalty in Bahawalpur. Journal of Sociological Research, 5(1).306-326. 
Table 1

Participants' Demographics $(N=527)$

\begin{tabular}{lccc}
\hline Variable & Group & Frequency & $\begin{array}{c}\text { Percentage } \\
(\%)\end{array}$ \\
\hline Gender & Male & 289 & $55 \%$ \\
\multirow{3}{*}{ Age } & Female & 238 & $45 \%$ \\
& $18-24$ & 91 & $17 \%$ \\
& $25-30$ & 158 & $30 \%$ \\
\multirow{3}{*}{ Occupation } & $31-40$ & 220 & $42 \%$ \\
& $>40$ & 58 & $11 \%$ \\
& Students & 209 & $40 \%$ \\
& Non-Students & 318 & $60 \%$ \\
\hline
\end{tabular}


Table 2

Dimensions of Social Media Uses and Gratifications (Perceived Media Values) Based on An

Exploratory Factor Analysis Using SPSS (N=527)

\begin{tabular}{|c|c|c|c|}
\hline Dimension & Coding & Item & $\begin{array}{c}\text { Factor } \\
\text { Loading }\end{array}$ \\
\hline \multirow{3}{*}{$\begin{array}{l}\text { Information (perceived } \\
\text { information value) }\end{array}$} & INFO1 & This social media platform can help me pass useful information. & 0.78 \\
\hline & INFO 2 & $\begin{array}{l}\text { This social media platform can help me receive instant } \\
\text { information (such as breaking news, local news, life service, } \\
\text { health information, etc.). }\end{array}$ & 0.78 \\
\hline & INFO 3 & $\begin{array}{l}\text { This social media platform can help me obtain information on } \\
\text { things that interest me. }\end{array}$ & 0.75 \\
\hline \multirow{3}{*}{$\begin{array}{l}\text { Entertainment } \\
\text { (Perceived entertainment } \\
\text { value) }\end{array}$} & ENT1 & $\begin{array}{l}\text { This social media platform can allow me to kill time when I am } \\
\text { bored. }\end{array}$ & 0.82 \\
\hline & ENT2 & $\begin{array}{l}\text { This social media platform can share or provide interesting } \\
\text { music and videos. }\end{array}$ & 0.81 \\
\hline & ENT3 & $\begin{array}{l}\text { This social media platform can share or provide interesting } \\
\text { leisure and entertainment topics. }\end{array}$ & 0.75 \\
\hline \multirow{3}{*}{$\begin{array}{c}\text { Social Networking } \\
\text { (Perceived social networking } \\
\text { value) }\end{array}$} & SN1 & $\begin{array}{l}\text { This social media platform has increased the connection between } \\
\text { me and my friends. }\end{array}$ & 0.81 \\
\hline & SN2 & $\begin{array}{l}\text { This social media platform has increased the connection between } \\
\text { me and my family. }\end{array}$ & 0.79 \\
\hline & SN3 & $\begin{array}{l}\text { This social media platform has increased my connection with my } \\
\text { colleagues. }\end{array}$ & 0.74 \\
\hline \multirow{3}{*}{$\begin{array}{l}\text { Social Status } \\
\text { (perceived social status value) }\end{array}$} & SS1 & This social media platform can allow me to impress others. & 0.84 \\
\hline & $\mathrm{SS} 2$ & $\begin{array}{l}\text { This social media platform can help me to be recognized by } \\
\text { others. }\end{array}$ & 0.80 \\
\hline & SS3 & This social media platform makes me look cool. & 0.76 \\
\hline \multirow{3}{*}{$\begin{array}{c}\text { Communication with } \\
\text { Government \& Organizations } \\
\text { (Perceived organizational } \\
\text { communication value) }\end{array}$} & ORG1 & $\begin{array}{l}\text { This social media platform has increased the connection between } \\
\text { the government and individuals. }\end{array}$ & 0.79 \\
\hline & ORG2 & $\begin{array}{l}\text { This social media platform has increased interaction between } \\
\text { companies within the industry. }\end{array}$ & 0.73 \\
\hline & ORG3 & $\begin{array}{l}\text { This social media platform can promote connections between } \\
\text { social organizations, such as companies and government } \\
\text { organizations. }\end{array}$ & 0.68 \\
\hline
\end{tabular}

Note. Factors were extracted by the principal component analysis and rotated orthogonally using the Kaiser Varimax Rotation Method in SPSS; rotation converges in 6 iterations. 
Table 3

Confirmatory Factor Analysis of Social Media Uses and Gratifications (Perceived Media

Values) Based on PLS-SEM $(N=527)$

\begin{tabular}{|c|c|c|c|c|c|c|}
\hline Dimension & $\begin{array}{c}\text { Factor } \\
\text { Loadings }\end{array}$ & $\begin{array}{l}\text { Composite } \\
\text { Reliability }\end{array}$ & AVE & & & \\
\hline INFO & $.793 \sim .840$ & 0.857 & 0.666 & & & \\
\hline ENT & $.784 \sim .853$ & 0.854 & 0.662 & & & \\
\hline $\mathbf{S N}$ & $.772 \sim .831$ & 0.848 & 0.651 & & & \\
\hline SS & $.793 \sim .855$ & 0.861 & 0.674 & & & \\
\hline ORG & $.738 \sim .796$ & 0.817 & 0.599 & & & \\
\hline TRS & $.775 \sim .825$ & 0.839 & 0.635 & & & \\
\hline Dimension & \multicolumn{6}{|c|}{ Discriminant Validity } \\
\hline & INFO & ENT & SN & SS & ORG & TRS \\
\hline INFO & 0.816 & & & & & \\
\hline ENT & 0.413 & 0.813 & & & & \\
\hline $\mathbf{S N}$ & 0.328 & 0.157 & 0.807 & & & \\
\hline SS & 0.186 & 0.14 & 0.289 & 0.821 & & \\
\hline ORG & 0.362 & 0.18 & 0.283 & 0.343 & 0.773 & \\
\hline TRS & 0.366 & 0.382 & 0.436 & 0.40 & 0.302 & 0.797 \\
\hline
\end{tabular}

Notes. The standardized coefficients are all significant; the "lower triangle" of Discriminant Validity represents the Pearson correlation coefficient between variables; the diagonal elements are the square root of AVE. INFO = information; ENT= entertainment; $\mathrm{SN}=$ social networking; $\mathrm{SS}=$ social status; $\mathrm{ORG}=$ organizational communication; $\mathrm{TRS}=$ trust in social media brands. 
Table 4

Paths in the Hypothesized Model Using PLS-SEM (Bootstrapping, N=1000)

\begin{tabular}{|c|c|c|c|c|c|}
\hline Paths & Estimate & S.D. & P-Value & $95 \% \mathrm{CI}$ & $\begin{array}{l}\text { Effect Size } \\
\text { f-square }\end{array}$ \\
\hline H1: Information $\rightarrow$ Trust & 0.11 & 0.05 & 0.023 & {$[0.01,0.2]$} & 0.01 \\
\hline $\mathrm{H} 2:$ Entertainment $\rightarrow$ Trust & 0.25 & 0.04 & $<0.001$ & {$[0.17,0.32]$} & 0.08 \\
\hline H3: Social networking $\rightarrow$ Trust & 0.27 & 0.05 & $<0.001$ & {$[0.18,0.37]$} & 0.1 \\
\hline H4: Social status $\rightarrow$ Trust & 0.25 & 0.04 & $<0.001$ & {$[0.16,0.33]$} & 0.08 \\
\hline $\begin{array}{l}\text { H5: Organizational } \\
\text { communication } \rightarrow \text { Trust }\end{array}$ & 0.06 & 0.04 & 0.163 & {$[-0.02,0.14]$} & 0.01 \\
\hline Information $\rightarrow$ Entertainment & 0.41 & 0.05 & $<0.001$ & {$[0.33,0.5]$} & 0.21 \\
\hline Information $\rightarrow$ Social networking & 0.26 & 0.05 & $<0.001$ & {$[0.17,0.35]$} & 0.07 \\
\hline Information $\rightarrow$ Social status & 0.07 & 0.05 & 0.161 & {$[-0.03,0.17]$} & 0.01 \\
\hline $\begin{array}{l}\text { Organizational communication } \rightarrow \\
\text { Social networking }\end{array}$ & 0.19 & 0.05 & 0.001 & {$[0.08,0.29]$} & 0.04 \\
\hline $\begin{array}{l}\text { Organizational communication } \rightarrow \\
\text { Social status }\end{array}$ & 0.32 & 0.05 & $<0.001$ & {$[0.22,0.42]$} & 0.10 \\
\hline \multicolumn{6}{|l|}{ Mediation Effects } \\
\hline Paths & Estimate & S.D. & P-Value & $95 \% \mathrm{CI}$ & \\
\hline $\begin{array}{l}\text { H6: Information } \rightarrow \text { Entertainment } \rightarrow \\
\text { Trust }\end{array}$ & 0.1 & 0.02 & $<0.001$ & {$[0.07,0.14]$} & \\
\hline $\begin{array}{l}\text { H7: Information } \rightarrow \text { Social } \\
\text { Networking } \rightarrow \text { Trust }\end{array}$ & 0.07 & 0.02 & $<0.001$ & {$[0.04,0.11]$} & \\
\hline $\begin{array}{l}\text { H8: Information } \rightarrow \text { Social status } \rightarrow \\
\text { Trust }\end{array}$ & 0.02 & 0.01 & 0.196 & {$[-0.01,0.05]$} & \\
\hline $\begin{array}{l}\text { H9: Organizational communication } \\
\rightarrow \text { Social Networking } \rightarrow \text { Trust }\end{array}$ & 0.05 & 0.02 & $<0.05$ & {$[0.02,0.09]$} & \\
\hline $\begin{array}{l}\text { H10: Organizational } \\
\text { communication } \rightarrow \text { Social status } \rightarrow \\
\text { Trust }\end{array}$ & 0.08 & 0.02 & $<0.001$ & {$[0.05,0.12]$} & \\
\hline \multicolumn{6}{|c|}{$\mathrm{R}^{2}$ (Explained Variance) \& $\mathrm{Q}^{2}$ (Predictive Relevance) of Latent Variables } \\
\hline Variables & $\mathbf{R}^{2}$ & $\mathbf{Q}^{2}$ & & & \\
\hline Entertainment value & 0.17 & 0.11 & & & \\
\hline Social status value & 0.12 & 0.08 & & & \\
\hline Social networking value & 0.14 & 0.08 & & & \\
\hline Social media brand trust & 0.37 & 0.23 & & & \\
\hline
\end{tabular}


Figure 1: Hypothesized Model Predicting Trust in Social Media Brands

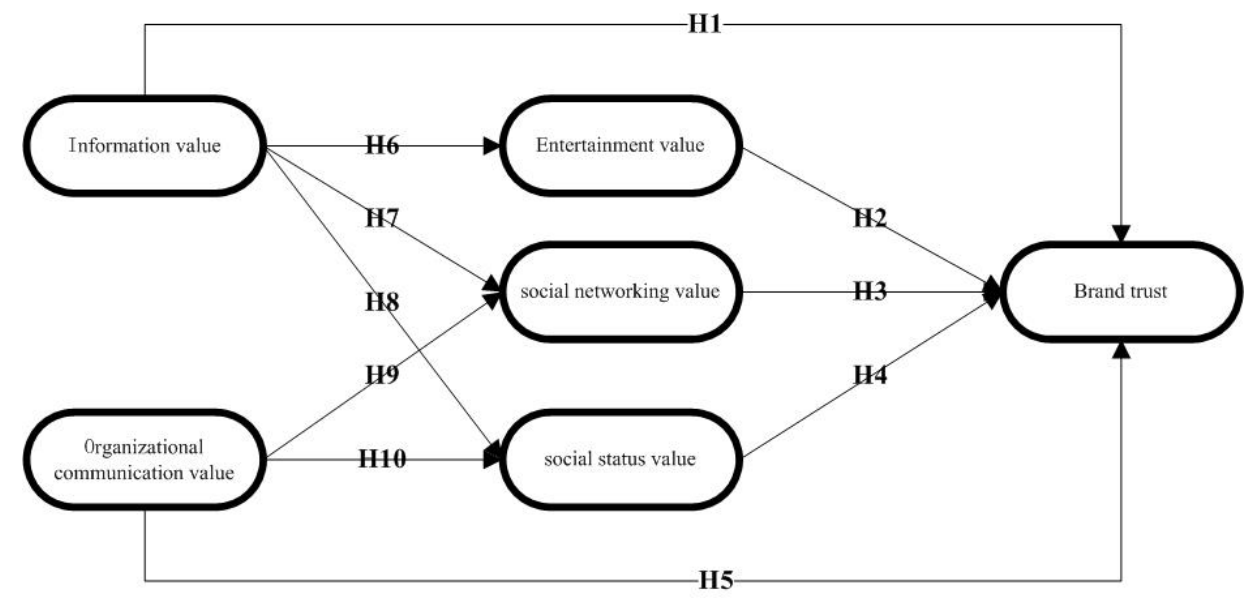

Figure 2. Results of the Hypothesized Model

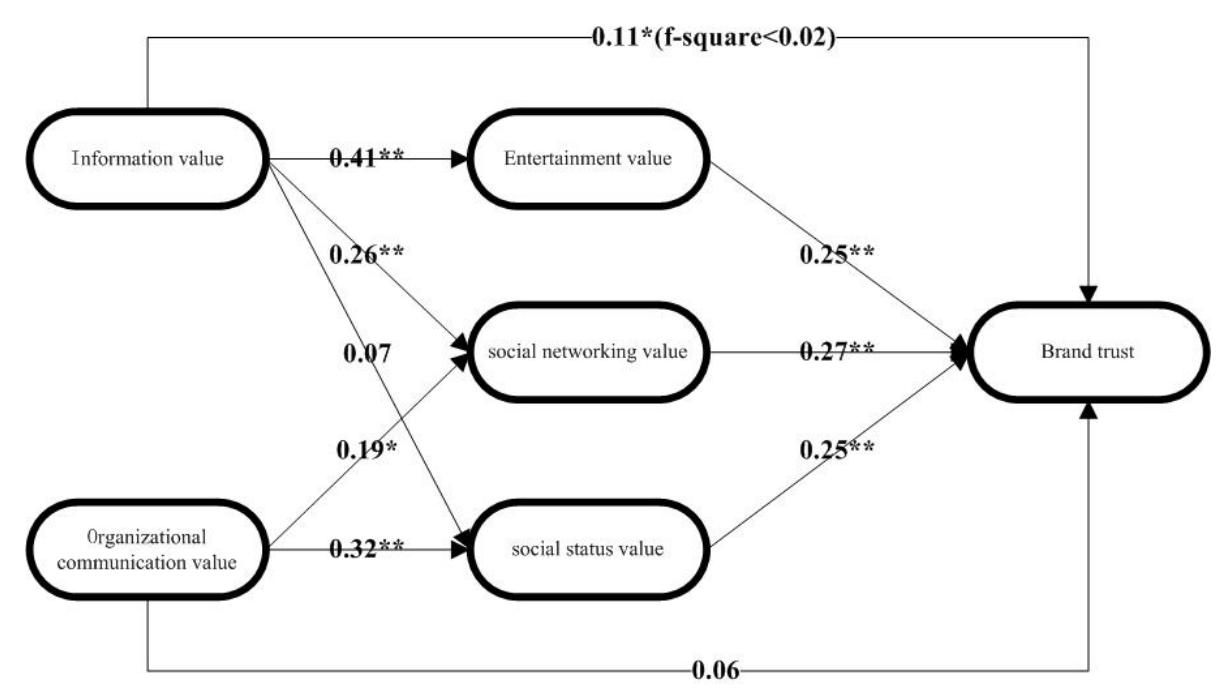

Figure 3: Final Model of Trust in Social Media Brands 


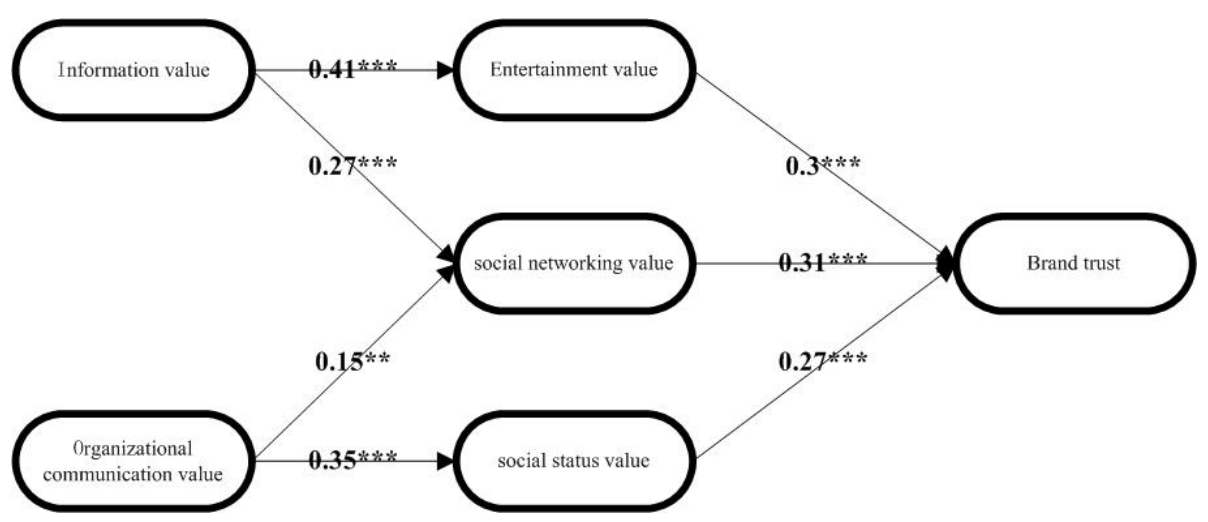

